УДК 347.78

DOI https://doi.org/10.51989/NUL.2021.6.6

\title{
ПРОБЛЕМИ ПРАВОВОЇ ОХОРОНИ КОМП'ЮТЕРНИХ ПРОГРАМ I БАЗ ДАНИХ: ОКРЕМІ ЗАУВАГИ В КОНТЕКСТІ РЕФОРМУВАННЯ ЗАКОНОДАВСТВА УКРАЇНИ
}

\author{
Якубівський Ігор Євгенович, \\ доктор юридичних наук, доцент, \\ професор кафедри цивільного права та процесу \\ Львівського національного університету імені Івана Франка

\section{Оприско Микола Васильович,} \\ кандидат юридичних наук, \\ доцент кафедри цивільного права та процесу \\ Львівського національного університету імені Івана Франка
}

У статті проаналізовано проблемні питання реформування законодавства України щодо комп'ютерних програм та баз даних як об'єктів права інтелектуальної власності. Констатовано, що віднесення комп'ютерних програм і баз даних до об'єктів авторського права сьогодні $\epsilon$ загальновизнаним підходом на рівні міжнародних документів BOIB, COT, ЄС. При цьому наголошено на тому, що об'єктами авторсько-правової охорони можуть бути лише оригінальні бази даних.

Звернута увага на колізії між ст. ст. 420, 433 ЦК України, за якими комп'ютерна програма і літературний твір позиціонуються як окремі категорії об'єктів авторського права, та ч. 4 ст. 433 ЦК України, яка фактично розглядає комп'ютерну програму як різновид літературного твору. Зроблено висновок, що для усунення цієї колізії доцільно вилучити ч. 4 ст. 433 ЦК України та перше речення ст. 18 зУ «Про авторське право і суміжні права».

Проаналізовано питання співвідношення понять «база даних (компіляція даних)», «збірник творів» та «складений твір». Висловлено позицію, що поняття «база даних (компіляція даних)» $\epsilon$ більш широким порівняно зі збірниками творів. Особливість останніх полягає в тому, що вони включають виключно твори, що охороняються авторським правом. Звернута увага на недоцільність подальшого збереження поняття «складений твір» у профільному законі.

Проаналізовано висловлені у вітчизняній правовій доктрині точки зору щодо перспективної моделі правової охорони нетворчих (неоригінальних) баз даних. Зазначено, що відсутність творчого характеру не може розглядатись як перешкода для віднесення нетворчих (неоригінальних) баз до об'єктів права інтелектуальної власності. Віднесення нетворчої бази даних до об'єктів права інтелектуальної власності зумовлює недоцільність врегулювання відносин щодо неї в конкурентному, інвестиційному, інформаційному законодавстві. Нетворчим базам даних варто надати правову охорону як самостійній категорії об'єктів права інтелектуальної власності, відмінній від об'єктів авторського права і суміжних прав, для чого відповідні положення доцільно закріпити в окремій главі Книги 4 ЦК України.

Ключові слова: комп'ютерна програма, база даних, компіляція даних, авторське право, право sui generis.

Yakubivskyi Ihor, Oprysko Mykola. The problems of legal protection of computer programs and databases: some remarks in the context of Ukrainian legislation reform

The article analyzes the problematic issues of reforming the legislation of Ukraine on computer programs and databases as objects of intellectual property rights. It is stated that the attribution of computer programs and databases to the objects of copyright as of today is a generally accepted approach at the level of international documents of WIPO, WTO, and EU. It is emphasized that the objects of copyright protection can only be original databases.

Attention is drawn to the collision between Art. 420, 433 of the Civil Code of Ukraine, according to which a computer program and a literary work are positioned as separate categories 
of copyright objects, and Part 4 of Art. 433 of the Civil Code of Ukraine, which, in fact, considers a computer program as a kind of literary work. It is concluded that to eliminate this conflict, it is advisable to remove Part 4 of Art. 433 of the Civil Code of Ukraine and the first sentence of Art. 18 of the Law on Copyright and Related Rights.

The issue of the relationship between the concepts of "database (data compilation)", "collection of works" and "composed work" is analyzed. The position is expressed that the concept of "database (data compilation)" is broader in comparison with collections of works. The peculiarity of the latter is that they include only works protected by copyright. Attention is drawn to the inexpediency of further preservation of the concept of "composed work" in the profile law.

The points of view expressed in the Ukrainian legal doctrine concerning the perspective model of legal protection of non-creative (non-original) databases are analyzed. It is noted that the lack of creative nature cannot be considered as an obstacle to the attribution of non-creative (nonoriginal) databases to the objects of intellectual property rights. Assigning a non-creative database to the objects of intellectual property rights makes it inexpedient to regulate the relationship to it in competition, investment, information legislation. Non-creative databases should be provided with legal protection as a separate category of the intellectual property objects, which don't belong to the copyright and related rights objects. The relevant provisions about non-creative databases should be enshrined in a separate chapter of Book 4 of the Civil Code of Ukraine.

Key words: computer program, database, data compilation, copyright, sui generis right.

Авторське право охороняє права на широке коло результатів творчої діяльності у галузі літератури, науки, мистецтва тощо. У Бернській конвенції про охорону літературних та художніх творів 1886 р. [1] об'єктами охорони визначено «літературні та художні твори», які, відповідно до ст. 2 (1) цієї Конвенції, охоплюють усі твори в галузі літератури, науки і мистецтва, яким би способом і в якій би формі вони не були виражені. Далі у зазначеній статті Бернської конвенції наведено досить великий, але водночас невичерпний перелік літературних та художніх творів.

Розвиток інформаційних технологій обумовив появу відносно нових результатів творчої діяльності, яких не існувало на час прийняття Бернської конвенції, а саме комп'ютерних програм і баз даних, що вимагало запровадження для таких об'єктів відповідного режиму їх правової охорони або за допомогою традиційних інститутів права інтелектуальної власності (авторське право, патентне право тощо), або шляхом визнання їх об'єктами права інтелектуальної власності sui generis, а також запровадження спеціального режиму правової охорони таких об'єктів.

У 1991 р. прийнята Директива 91/250/ ЄEC про правову охорону комп'ютерних програм [2], у якій закладено перший варіант, а саме надання охорони комп'ютерним програмам за допомогою авторського права як літературним творам у розумінні Бернської конвенції про охорону літера- турних та художніх творів. Цей же підхід надалі підтримано в чинній Директиві ЄC про правову охорону комп'ютерних програм 2009 р. [3].

Щодо баз даних, то прийнята у 1996 р. Директива ЄC про правову охорону баз даних [4] передбачила правову охорону баз даних, що $\epsilon$ результатами творчої діяльності автора, за допомогою авторського права (ст. 3), а нетворчих (неоригінальних) баз даних - за допомогою права особливого роду sui generis (ст. 7).

Віднесення комп'ютерних програм та баз даних, до об'єктів авторського права отримало відображення у прийнятій у рамках ГАТТ у 1994 р. Угоді про торговельні аспекти прав інтелектуальної власності (TRIPS) (ст. 10) [5], а згодом - у Договорі BOIB про авторське право 1996 р. [6].

Отже, віднесення комп'ютерних програм і баз даних до об'єктів авторського права сьогодні $\epsilon$ загальновизнаним підходом на рівні міжнародних документів ВОIВ, СОТ, ЄС. Єдине, що стосовно баз даних об'єктами авторсько-правової охорони можуть бути лише оригінальні бази даних, тобто такі, які за підбором або розміщенням інформації становлять результат творчої діяльності особи, яка їх створила. Щодо нетворчих (неоригінальних) баз даних, то їх не можна відносити до об'єктів авторського права, оскільки останнє охороняє лише об'єкти, які мають творчий характер.

Загалом зазначені підходи відображено в національному законодавстві України 
(ст. 433 ЦК України [7], ст. 8 ЗУ «Про авторське право і суміжні права» [8]), за яким комп'ютерні програми і бази даних віднесено до об'єктів авторського права. Водночас відповідні положення потребують певних уточнень, на що доцільно звернути увагу в процесі оновлення (рекодифікації) ЦК України та під час підготовки нового профільного закону про авторське право і суміжні права.

Так, ч. 4 ст. 433 ЦК України передбачено, що комп'ютерні програми охороняються як літературні твори. Аналогічне положення міститься у ст. 18 ЗУ «Про авторське право і суміжні права».

Наведене положення відтворює ст. 4 Договору BOIB про авторське право, проте в усіченому вигляді, адже остання передбачає, що комп'ютерні програми охороняються як літературні твори в розумінні ст. 2 Бернської конвенції. В цьому разі варто враховувати, що Договір ВОІВ про авторське право був прийнятий у зв'язку з необхідністю адаптації закріпленої Бернською конвенцією системи охорони авторського права до нових реалій, пов'язаних, зокрема, з розвитком комп'ютерної техніки. Як зазначено у його ст. 1, цей Договір $\epsilon$ спеціальною угодою в рамках значення ст. 20 Бернської конвенції, ніщо в цьому Договорі не змінює наявних зобов'язань Договірних Сторін згідно з Бернською конвенцією. Отже, положення ст. 4 Договору ВОІВ про авторське право потрібно розуміти так, що комп'ютерні програми $\epsilon$ об'єктами авторського права, на які поширюється режим правової охорони, встановлений Бернською конвенцією для літературних творів. Однак це зовсім не означає, що між комп'ютерними програмами і літературними творами поставлено знак рівності. Як зазначають фахівці ВOIB, комп'ютерні програми не можна віднести до категорії письмових творів, книг або наукових робіт [9, с. 528].

Наприклад, у Великобританії ст. 3 (1) Закону «Про правову охорону комп'ютерних програм» передбачено, що задля правової охорони комп'ютерні програми прирівнюються до літературних творів [10, с. 112$]$.

Наведене положення національного законодавства України про те, що комп'ютерні програми охороняються як літе- ратурні твори, $є$ неточним. Тим більше, що у ст. ст. 420, 433 ЦК України комп'ютерні програми структурно відмежовані від літературних творів. У цьому аспекті можна говорити про існування колізії між ст. ст. 420, 433 ЦК України, за якими комп'ютерна програма і літературний твір позиціонуються як окремі категорії об'єктів авторського права, та ч. 4 ст. 433 ЦК України, яка фактично розглядає комп'ютерну програму як різновид літературного твору. Усунення цієї колізії теоретично можливе двома такими шляхами:

- доповнення ч. 4 ст. 433 ЦК України та першого речення ст. 18 ЗУ «Про авторське право і суміжні права» словами «в розумінні Бернської конвенції про охорону літературних та художніх творів»;

- вилучення ч. 4 ст. 433 ЦК України та першого речення ст. 18 ЗУ «Про авторське право і суміжні права».

Вважаємо більш доцільним другий варіант. По-перше, норма про те, що комп'ютерні програми охороняються як літературні твори в розумінні Бернської конвенції, міститься у ст. 4 Договору ВОІВ про авторське право, в якому Україна бере участь і який $є$ частиною національного законодавства нашої держави. Отже, дублювати цю норму у ЦК України чи профільному законі особливої потреби немає. Тим паче, що з огляду на умови, в яких приймався Договір ВОІВ про авторське право, та зміст його положень стосовно зв'язку з Бернською конвенцією ст. 4 цього Договору $\epsilon$ цілком зрозумілою і виправданою, чого не можна сказати про усічений варіант відповідної норми, закріплений ч. 4 ст. 433 ЦК України та ст. 18 ЗУ «Про авторське право і суміжні права». По-друге, ЦК України та ЗУ «Про авторське право і суміжні права» встановлюють уніфікований режим правової охорони творів, що $€$ об'єктами авторського права. Спеціальні норми закріплені у профільному законі лише стосовно деяких категорій творів (аудіовізуальні твори - ст. 17, комп'ютерні програми - ст. 18, складені твори - ст. 19 тощо), однак закон не містить відповідних спеціальних норм саме щодо літературних творів. Отже, положення ч. 4 ст. 433 ЦК України та першого речення ст. 18 ЗУ «Про авторське право і суміжні права» фактично жодного зміс- 
товного навантаження не несуть, тому їх вилучення ніяким чином не позначиться на режимі правової охорони комп'ютерних програм.

Щодо правової охорони баз даних, то ст. 420 ЦК України до об'єктів права інтелектуальної власності віднесено компіляції даних (бази даних). Відповідно до ч. 1 ст. 433 ЦК України, об'єктами авторського права $\epsilon$ компіляції даних (бази даних), якщо вони за добором або упорядкуванням їх складових частин $\epsilon$ результатом інтелектуальної діяльності.

Варто звернути увагу на те, що об'єктами права інтелектуальної власності, відповідно до ст. 420 ЦК України, визначено компіляції даних (бази даних) незалежно від того, чи $€$ вони результатами творчої діяльності. Лише ті бази даних, які за добором або упорядкуванням їх складових частин $\epsilon$ результатами творчої діяльності, віднесено до об'єктів авторського права. Загалом такий підхід відповідає Угоді TRIPS, Договору BOIB про авторське право та Директиві 96/9/ЄС.

Водночас варто звернути увагу на те, що ст. 433 ЦК України розмежовує серед об'єктів авторського права, з одного боку, збірники творів, якщо вони за добором або упорядкуванням їх складових частин $€$ результатом інтелектуальної діяльності, та, з іншого боку, компіляції даних (бази даних).

У ч. 1 ст. 8 ЗУ «Про авторське право і суміжні права» серед об'єктів авторського права названо окремо бази даних (п. 4) і збірники творів, збірники обробок фольклору, енциклопедії та антології, збірники звичайних даних, інші складені твори за умови, що вони $\epsilon$ результатом творчої праці за добором, координацією або упорядкуванням змісту без порушення авторських прав на твори, що входять до них як складові частини (п. 15). Проте у ст. 19 цього Закону, яка присвячена складеним творам, міститься норма, що «передбачена цією частиною правова охорона баз даних не поширюється на самі дані чи інформацію і не зачіпає будь-яке авторське право, що належить до самих даних чи інформації, які містяться у базі даних».

Згідно з визначенням, закріпленим ст. 1 профільного Закону, база даних (компіляція даних) - це сукупність творів, даних або будь-якої іншої незалежної інформа- ції у довільній формі, в тому числі електронній, підбір і розташування складових частин якої та ії упорядкування $\epsilon$ результатом творчої праці, а складові частини якої $€$ доступними індивідуально і можуть бути знайдені за допомогою спеціальної пошукової системи на основі електронних засобів (комп'ютера) чи інших засобів.

Як бачимо, законодавство України не містить послідовної та однозначної позиції щодо співвідношення складених творів і баз даних. У літературі з цього питання теж немає єдності думок. Одні науковці вважають, що бази даних мають правовий режим складених творів [11, с. $143-144$; 12 , с. $155 ; 13$, с. 82,85$]$, проте у багатьох виданнях з права інтелектуальної власності складені твори та бази даних розглядаються як самостійні категорії об'єктів авторського права [14, с. 185-190; 15 , с. $98-99 ; 16$, с. $111-112]$.

У ст. 1 Директиви 96/9/ЄС зазначено, що вона стосується правового захисту баз даних у будь-якій формі. Для досягнення цілей цієї Директиви «база даних» означає зібрання незалежних творів, даних чи інших матеріалів, які систематично чи методично упорядковані і доступні індивідуально за допомогою електронних та інших засобів.

Для тлумачення поняття «база даних» потрібно взяти до уваги окремі положення ії преамбули, такі як:

- Директива захищає зібрання, що іноді називаються компіляціями, робіт, даних чи інших матеріалів, які упорядковуються, зберігаються і до яких отримується доступ за допомогою засобів, що включають електронні, електромагнітні та електрооптичні процеси або аналогові процеси (п. 13);

- захист, відповідно до цієї Директиви, повинен поширюватись на неелектронні бази даних (п. 14);

- поняття «база даних» слід розуміти як таке, що включає літературні, художні, музичні чи інші зібрання творів або зібрання інших матеріалів, таких як тексти, звуки, образи, цифри, факти та дані, враховуючи, що воно має охоплювати зібрання незалежних робіт, даних чи інших матеріалів, які систематично або методично упорядковані і до яких може бути отримано окремий доступ (п. 17). 
Отже, Директива трактує поняття «база даних» доволі широко, включаючи в нього бази даних в іншій формі, ніж електронна. Коментуючи положення Директиви 96/9/ $\in C$, Ю.М. Капіца підкреслив, що зазначене визначення включає не лише дані в електронному вигляді, але й енциклопедії, словники, збірники наукових праць, антології, довідники вулиць, календарні плани, підшивки замовлень та інвойсів, листки з цінами на товари, газети та журнали [17, с. 239].

Цікаво відзначити, що у Великобританії внаслідок внесення змін у Закон «Про авторське право, дизайн і патенти», пов'язаних із необхідністю врахування положень Директиви 96/9/ЄС, бази даних були вилучені з категорії «таблиці і збірники» і нині розглядаються як окремий вид твору. У зв'язку з цим Л. Бентлі та В. Шерман зазначають, що наділення баз даних самостійною категорійністю дало змогу передбачити в законі особливий зміст застосовуваного до них критерія оригінальності (щодо того, що застосовується до таблиць і збірників) [10, с. 110].

Повертаючись до регулювання цього питання у національному законодавстві України, маємо зазначити, що передбачене ЦК України поняття «збірники творів» і закріплена ЗУ «Про авторське право і суміжні права» категорія «складені твори» не $\epsilon$ тотожними. Перше включає лише твори, тобто об'єкти авторського права. Це відповідає поняттю «збірники літературних чи художніх творів» (англ. collections of literary or artistic works; фp. les recueils d'œuvres littéraires ou artistiques), передбаченому ст. 2 (5) Бернської конвенції. Стосовно поняття «складений твір», то, відповідно до ст. 19 ЗУ «Про авторське право і суміжні права», такий може містити «твори та (або) інші дані». Таке широке розуміння складеного твору практично ототожнює його з базою даних (компіляцією даних). 3 огляду на те, що закріплене ст. 1 ЗУ «Про авторське право і суміжні права» визначення бази даних (компіляції даних) передбачає його широке тлумачення, що не обмежується лише базами даних в електронній формі, постає питання доцільності позиціонування складених творів і баз даних як окремих категорій об'єктів авторського права.
Судовій практиці вже відомі випадки застосування до збірників положень про бази даних. Як приклад можна навести спір, що стосувався договору на видання книги, яка становила збірку статей, документів, фотографій щодо прийняття Декларації про державний суверенітет України. Верховний Суд, посилаючись на визначення поняття «база даних (компіляція даних)» у ст. 1 ЗУ «Про авторське право і суміжні права» та на ст. 5 Договору BOIB про авторське право, дійшов висновку, що результат творчої діяльності при компіляції полягає у підборі, організації, систематизації певних творів або іншої інформації в об'єктивній формі, ії упорядники набувають авторських прав, а об'єкт вважається твором у розумінні Закону України «Про авторське право і суміжні права». Отже, цей збірник $\epsilon$ компіляцією даних і $€$ результатом творчої праці [18].

Вважаємо, що «база даних (компіляція даних)» $\epsilon$ більш широким поняттям, ніж поняття «збірники творів». Особливість останніх полягає в тому, що вони включають твори, що охороняються авторським правом, тому для включення кожного окремого твору до збірника потрібен дозвіл суб'єкта авторського права на такий твір. Щодо поняття «складений твір», то його подальше збереження у профільному законі видається недоцільним, принаймні у його теперішньому широкому розумінні.

Таким чином, у процесі рекодифікації (оновлення) ЦК України та підготовки нового профільного закону про авторське право і суміжні права доцільно у ч. 1 ст. 433 ЦК України з п. 1 виключити останній абзац, а п. 3 викласти у такій редакції: «3) компіляції даних (бази даних), у тому числі збірники творів, якщо вони за добором або упорядкуванням їх складових частин $\in$ результатом творчої діяльності;»; такий же підхід закріпити у новому Зу «Про авторське право і суміжні права», в якому серед об'єктів авторського права не виокремлювати категорію «складені твори».

Як уже зазначалося, ст. 420 ЦК України відносить до об'єктів права інтелектуальної власності бази даних незалежно від того, мають вони творчий характер чи ні. Проте, на відміну від творчих (оригінальних) баз даних, які віднесені до об'єктів 
авторського права, жодних спеціальних норм, які би закріплювали правовий режим нетворчих (неоригінальних) баз даних, у ЦК України не передбачено.

Аналогічний підхід спостерігаємо в Угоді про асоціацію [19], де положення про бази даних містяться в підрозд. 1 ч. 2 гл. 9 «Авторське право та суміжні права» (ст. ст. 185-189) та у ч. 3 гл. 9 «Захист прав інтелектуальної власності» (примітка до ст. 230).

У ст. 185 Угоди про асоціацію передбачено загальне визначення баз даних: для досягнення цілей цієї Угоди термін «база даних» означає сукупність незалежних творів, даних або іншої інформації, розташованих у систематизованому або упорядкованому вигляді та доступних для будь-якої особи за допомогою електронних або інших засобів.

Наведене визначення відповідає його розумінню у ст. 1 Директиви 96/9/ЄС і охоплює як творчі, так і нетворчі бази даних. При цьому варто звернути увагу на те, що таке розуміння баз даних стосується тексту Угоди про асоціацію загалом. Проте для досягнення цілей підрозд. 1 ч. 2 гл. 9 «Авторське право та суміжні права» Угоди про асоціацію $є$ лише бази даних, які внаслідок підбору або розташування їхнього інформаційного наповнення $€$ результатом творчої праці автора.

щодо нетворчих баз даних, для яких Директивою 96/9/ЄС передбачено право sui generis, у ч. 2 гл. 9 Угоди про асоціацію жодних спеціальних положень, які би передбачали режим їхньої правової охорони, не закріплено. Водночас у примітці до ст. 230 Угоди про асоціацію зазначено, що для досягнення цілей ч. 3 гл. 9 «Захист прав інтелектуальної власності» поняття «права інтелектуальної власності» має принаймні охоплювати право sui generis виробника бази даних.

Такий підхід Угоди про асоціацію важко визнати послідовним, оскільки необхідною передумовою захисту прав $€$ їх належність відповідному суб'єкту, що стосовно сфери інтелектуальної власності вимагає, аби відповідне право було закріплено ехpressis verbis на рівні законодавства. Нині законодавство України не містить положень щодо охорони прав на нетворчі бази даних, що унеможливлює виконання Україною своїх зобов'язань за Угодою про асоціацію стосовно захисту прав на такі об'єкти, тому законодавство в цій частині потребує внесення відповідних змін. У вітчизняній літературі запропоновані такі варіанти законодавчого закріплення прав sui generis на нетворчі бази даних:

1) регулювання їх окремою гл. Книги 4 ЦК України (Н.Є. Яркіна [13, с. 90]);

2) прийняття спеціального закону щодо охорони прав на такті об'єкти (Л.Т. Комзюк [20, с. 218]);

3) введення відповідних норм у Закони України «Про інвестиційну діяльність» та «Про захист від недобросовісної конкуренції» (Ю.М. Капіца [17, с. 248-249]);

4) доповнення профільного закону положеннями про право sui generis упорядника нетворчої бази даних як новий вид суміжних прав (В.С. Дроб'язко [21, с. 31]);

5) регулювання відповідних відносин нормами інформаційного законодавства (O.I. Яременко [22, с. 23]).

Вважаємо найбільш правильною першу з наведених позицій, на підтримку і в розвиток якої варто зазначити таке.

1) Нетворча база даних може бути визнана об'єктом права інтелектуальної власності. Зазначимо, що в праві $\in C$ охорона баз даних, включаючи право sui generis на нетворчі бази даних, належить до сфери інтелектуальної власності [23, с. 110-124]. Те, що нетворча база даних не $\epsilon$ результатом творчої діяльності, не може розглядатись як перешкода для її віднесення до об'єктів права інтелектуальної власності, як вважають деякі дослідники. Відповідно до ч. 1 ст. 418 ЦК України, право інтелектуальної власності - це право особи на результат інтелектуальної, творчої діяльності або на інший об'єкт права інтелектуальної власності, визначений цим Кодексом та іншим законом. 3 цієї норми випливає, що не кожен об'єкт права інтелектуальної власності $\epsilon$ результатом творчої діяльності [24, с. 62-66]. Отже, за умови закріплення у ЦК України положень про право інтелектуальної власності на нетворчу базу даних з позиції дефініції ч. 1 ст. 418 цей об'єкт буде належати до «інших об'єктів права інтелектуальної власності, визначених цим Кодексом».

2) Віднесення нетворчої бази даних до об'єктів права інтелектуальної власності 
обумовлює належність відносини щодо цього об'єкта до сфери регулювання законодавства про інтелектуальну власність (насамперед ЦК України), а не конкурентного, інвестиційного, інформаційного законодавства.

3) Нетворчу базу даних доцільно розглядати як окремий об'єкт права інтелектуальної власності. В актах $€ C$ правовий режим такого об'єкта визначається не через авторське право або суміжні права, а саме як право особливого роду - sui generis, тому важко підтримати ідею щодо віднесення права виробника нетворчої бази даних до категорії суміжних прав. В Угоді про асоціацію право sui generis виробника бази даних не віднесено до суміжних прав (ст. 164), а розглядається як окрема від суміжних прав категорія прав інтелектуальної власності (примітка до ст. 230).

Отже, положення про право інтелектуальної власності на нетворчі бази даних доцільно закріпити у ЦК України окремою главою у Книзі 4. Враховуючи підтримувану нами позицію щодо недоцільності збереження у ЦК України положень про наукове відкриття [25, с. $195 ; 26$, с. 151 ; 27, с. 165-166], зазначаємо, що замість норм про цей об'єкт, вміщених у гл. 38 ЦК України, доцільно прописати норми про право інтелектуальної власності на нетворчу базу даних. При цьому прийняття окремого закону щодо розглядуваного об'єкта на цьому етапі вважаємо недоцільним і дещо передчасним. Директива 96/9/ЄС пропонує відносно небагато норм про право sui generis на нетворчу базу даних, а на їх основі навряд чи вдасться підготувати повноцінний окремий закон, тому більш доцільно прописати відповідні положення саме у ЦК України окремою главою Книги 4.

Отже, в процесі оновлення (рекодифікації) положень ЦК України та підготовки нового профільного закону про авторське право і суміжні права доцільно взяти до уваги таке.

1) Комп'ютерні програми та літературні твори являють собою самостійні категорії об'єктів авторського права. Отже, з ЦК України та ЗУ «Про авторське право і суміжні права» доцільно виключити положення про те, що комп'ютерні програми охороняються як літературні твори.

2) Творчі (оригінальні) бази даних як окрема категорія об'єктів авторського права включають, зокрема, збірники літературних та художніх творів. Збереження у законодавстві України поняття «складений твір» $є$ недоцільним.

3) Нетворчим (неоригінальним) базам даних варто надати правову охорону як самостійній категорії об'єктів права інтелектуальної власності, відмінній від об'єктів авторського права і суміжних прав, для чого відповідні положення доцільно прописати в окремій главі Книги 4 ЦК України.

\section{ЛITEPATУРА:}

1. Бернська конвенція про охорону літературних і художніх творів від 9 вересня 1886 р. (Паризький акт від 24 липня 1971 р.). Зібрання чинних міжнародних договорів України. 2006. № 5 (Кн. 2). С. 1247.

2. Council Directive $91 / 250 /$ EEC of 14 May 1991 on the legal protection of computer programs. URL: https://eur-lex.europa.eu/legal-content/EN/ALL/?uri=celex\%3A31991L0250.

3. Directive 2009/24/EC of the European Parliament and of the Council of 23 April 2009 on the legal protection of computer programs. URL: https://eur-lex.europa.eu/legal-content/en/ TXT/?uri=CELEX\%3A32009L0024.

4. Directive 96/9/EC of the European Parliament and of the Council of 11 March 1996 on the legal protection of databases. URL: https://eur-lex.europa.eu/legal-content/EN/ TXT/?uri=celex\%3A31996L0009.

5. Угода про торговельні аспекти прав інтелектуальної власності, прийнята 15 квітня 1994 p. URL: https://zakon.rada.gov.ua/laws/show/981_018\#Text.

6. Договір Всесвітньої організації інтелектуальної власності про авторське право, прийнятий на Дипломатичній конференції 20 грудня 1996 p. URL: https://zakon.rada.gov.ua/laws/ show/995_770\#Text.

7. Цивільний кодекс України : Закон України від 16 січня 2003 р. № 435-IV. Відомості Верховної Ради України. 2003. № 40-44. С. 356. 
8. Про авторське право і суміжні права : Закон України від 23 грудня 1993 р. № 3792-XII (в редакції Закону від 11 липня 2001 р. № 2627-III). Відомості Верховної Ради України. 2001. № 43. С. 214.

9. Основи інтелектуальної власності : за матеріалами ВОІВ. Київ : Ін Юре, 1999. 578 с.

10. Бентли Л., Шерман Б. Право интеллектуальной собственности: авторское право / пер. с англ. В.Л. Вольфсона. Санкт-Петербург : Юридический центр Пресс, 2004. 535 с.

11. Право інтелектуальної власності: академічний курс : підручник для студентів вищих навчальних закладів / за ред. О.П. Орлюк, О.Д. Святоцького. Київ : Ін Юре, 2007. 696 с.

12. Сергеев А.П. Право интеллектуальной собственности в Российской Федерации : учебник. 2-е изд., перераб. и доп. Москва : ТК Велби ; Проспект, 2005. 752 с.

13. Яркіна Н.Є. Правова охорона баз даних: режим авторсько-правовий та "sui generis". Проблеми законності. 2008. Вип. 99. С. 81-90.

14. Інтелектуальне право України / за заг. ред. О.С. Яворської. Тернопіль : Підручники і посібники, 2016. 608 с.

15. Харитонова О.І. та ін. Право інтелектуальної власності : підручник. Київ : Юрінком Інтер, 2015. $540 \mathrm{c}$.

16. Цивільний кодекс України: науково-практичний коментар (пояснення, тлумачення, рекомендації з використанням позицій вищих судових інстанцій, Міністерства юстиції, науковців, фахівців). Т. 6 : Право інтелектуальної власності / за ред. І.В. Спасибо-Фатєєвої. Харків : Право, 2011. 592 с.

17. Капіца Ю.М., Ступак С.К., Жувака О.В. Авторське право і суміжні права в Європі : монографія. Київ : Логос, 2012. 696 с.

18. Постанова Першої судової палати КЦС Верховного Суду від 3 квітня 2019 р. у справі № 2-4268/11. URL: https://reyestr.court.gov.ua/Review/81652254.

19. Угода про асоціацію між Україною, з однієї сторони, та Європейським Союзом, Європейським співтовариством з атомної енергії і їхніми державами-членами, з іншої сторони, ратифікована із заявою Законом України від 16 вересня 2014 р. Відомості Верховної Ради України. 2014. № 40. С. 2021.

20. Комзюк Л.Т. Проблеми гармонізації охорони прав на бази даних (у контексті європейської інтеграції країн Центрально-Східної Європи). Вісник Харківського національного університету внутрішніх справ. 2010. № 2. С. 213-219.

21. Дроб'язко В.С. Охорона баз даних в Україні. Теорія і практика інтелектуальної власності. 2008. № 6. С. 26-31.

22. Яременко О.І. Правова охорона баз даних в Україні. Правова інформатика. 2011. № 1 (29). C. 17-24.

23. Капіца Ю.М. Право інтелектуальної власності Європейського Союзу: формування, інститути, напрями розвитку : монографія. Київ : Академперіодика, 2017. 664 с.

24. Якубівський I.Є. Набуття, здійснення та захист майнових прав інтелектуальної власності в Україні : монографія. Львів : ЛНУ ім. Івана Франка, 2018. 522 с.

25. Кодифікація приватного (цивільного) права України / за ред. А.С. Довгерта. Київ : Український центр правничих студій, 2000. 336 с.

26. Шишка Р.Б. Охорона права інтелектуальної власності: авторсько-правовий аспект : монографія. Харків : вид-во Національного університету внутрішніх справ, 2002. 368 с.

27. Якубівський І.Є. Об'єкти права інтелектуальної власності з позиції рекодифікації цивільного законодавства України. Актуальні проблеми правознавства. 2021. Вип. 2 (26). С. 162-170. 